\title{
MOTIVET DER BLEV VÆK FOR LITTERATURTEORIEN
}

I 2013 udkom en diger grundbog Litteratur. Introduktion til teori og analyse med hele seks redaktører og et utal af skribenter (Kjældgaard m.fl. 2013). På den omfangsrige liste over de emner, der behandles i bogen, støder man på en del fænomener, der måske ville have fået ældre litteraturforskere til at løfte et øjenbryn: begær, affekt, sansning, køn, natur, sted, erindring, mobilitet. De ville nok have sagt - det er i hvert fald mit gæt - at disse emner naturligvis kan indgå i mange litterære værker, men de kan da ikke af den grund opfattes som begreber inden for litteraturteori/-analyse. Et litterært værk kan handle om alt, men derfor er litteraturvidenskaben ikke en disciplin om alt.

Når man læser forordet, erfarer man imidlertid, at de eksotiske emners tilstedeværelse skyldes, at litteraturstudiet ikke længere kan opdeles i henholdsvis litteraturhistorie og litteraturanalyse, sidstnævnte med en angiveligt ahistorisk og kontekstløs gennemgang af kanoniserede metoder og begreber:

Der er imidlertid kommet et tredje element ind i litteraturforskningen, som mere og mere synes at forstyrre denne opdeling. Det er teori. Ikke teori forstået som en refleksion over og et grundlag for metode og analyse, heller ikke teori som en måde at besvare et problem på, men teori som et fælles humanistisk felt af mere eller mindre velorganiserede ideer og begreber, der lader sig flytte fra videnskab til videnskab. (7, min fremhævning) 
For mig lyder det som en opskrift på anarki med disse mere eller mindre velorganiserede ideer, der lader sig flytte rundt på. De ældre litteraturforskere ville nok også undre sig over fraværet af to klassiske og helt basale litteraturvidenskabelige begreber som tema og motiv. De står hverken på emnelisten eller i emneregisteret. Hvordan kan det mon være?

Mit gæt vil være, at de betragtes som så banale og selvfølgelige, at de ikke fortjener en nærmere overvejelse. De har at gøre med litteraturens indholdsside (det, der repræsenteres i tekster, det som tekster "handler om"), og den dimension var i mange år, især i 1980'erne og 90'erne, fortrængt til fordel for et stærkt fokus på litteraturens udtryksside. I de senere år er indholdssiden imidlertid blevet inviteret inden for igen i litteraturvidenskaben, bl.a. ud fra hensyn til tværfagligt og emneorienteret samarbejde (anvendelse af litterære tekster som "kilder" til andre typer undersøgelser). Og mit videre gæt er, at de mobile begreber fra teorierne fortrænger disse klassiske indholdsbegreber; de mobile begreber bliver set som mere differentierede bud på, hvad tekster kan handle om (sted, køn, mobilitet m.m.), og også mere sofistikerede bud, fordi de kan gå på tværs af både indholds- og udtryksside og tekst-/læserdimension (affekt, sansning m.m.). Dette indebærer imidlertid, at man inviterer indholdsdimensionen ind igen uden at tænke fundamentalt og systematisk over den. Gjorde man det, ville man efter min vurdering ikke kunne undvære klassiske indholdsbegreber som tema og motiv. Risikoen er, at litteraturvidenskaben ender som et under-teoretiseret område, der på overfladen tager sig over-teoretiseret ud. Den taktiske fordel ved det er, at litteraturvidenskaben ser ud til at kunne byde sig til som en fleksibel partner i tværfaglige og ad hoc prægede samarbejdsprojekter, men på den længere og strategiske bane risikerer disciplinen at miste sin identitet og kohærens, og dermed også undergrave de reelle muligheder for at kunne producere erkendelser i et tværfagligt samarbejde.

\section{FORSKELLEN PA TEMA OG MOTIV}

Hvad er forskellen på tema og motiv? Er der nogen forskel? En ulempe ved de to klassiske begreber er, at de har været i omløb så længe, at de virker næsten intetsigende eller dagligsprogligt selvfølgelige. Tema og motiv er vel bare synonymer for det en tekst handler om i samme forstand, som man 
kan sige om et billede, at "billedet forestiller (et eller andet)." Det er også derfor, "tematisk" ofte har kunnet fungere som skældsord: "Du forholder dig kun tematisk til teksten". Det blev især almindeligt efter, at udtrykssiden blev opprioriteret.

I en lidt ældre grundbogsartikel om "tema" har Erik Nielsen (Nielsen 1995) nogle både præcise og paradoksale formuleringer, der fanger det forhold, at temaet i en tekst jo ikke behøver blive benævnt eller overhovedet fremstå direkte identificérbart. Nielsen formulerer det på følgende måder: Temaet organiserer teksten, men har ingen egen eksistens. Det lever ved det konkrete, men det er selv abstrakt. Det formgiver det sanselige, men det er selv usanseligt. Han sætter trumf på med en formulering om at temaet på én gang er kunstværkets hjerte og dets blinde passager, og der hvor kunst og virkelighed sætter hinanden stævne. Litteraturlæsning bliver nemlig eksistentiel i temaanalysen.

Nielsen argumenterer ny-kritisk og ser det litterære kunstværk som både en totalitet og som en erkendelsesform. I arven fra den strukturelle semantik udvikler han også temaet som et energiladet spændingsfelt, der kræver to poler. Fra min studietid i 1970'erne husker jeg denne form for "tematisk analyse" som relativt ufrugtbar, fordi de tematiske modsætningspar ofte blev meget abstrakte og/eller meget banale (natur versus kultur, liv versus død osv.).

Jeg foretrækker derfor at lade begrebet om tema henstå som en lidt vagere abstraktionskategori. I forhold til Nielsens ny-kritiske horisont må det i dag præciseres, at temaet altid er produktet af en fortolkningsindsats, så sandt som man ikke nødvendigvis kan udpege det tekstuelt, og de fleste tekster også kan tillægges flere temaer. Det er med andre ord ikke et begreb i særlig streng forstand. Anderledes forholder det sig med motivet, som jeg nu vil vende mig imod.

I det litterære værk befinder motivet sig nemlig for mig at se mellem tema (dvs. det abstrakt formulerede idéindhold) og tekstlig realisering (dvs. den foreliggende individuelle tekst). ${ }^{1}$ Motivet er en typisk situation, en genkommende begivenhed, en bestemt konstellation mellem elementer,

1 Denne forståelse af motivet passer meget godt sammen med, hvad man kan finde i lidt ældre litteraturvidenskabelige håndbøger eller grundbøger, f.eks. Kayser 61-73. 
der kan genkendes og genfindes uafhængigt af den individuelle tekst, som den dog samtidig fungerer handlingsgenererende for. Eller som det hedder i Torben Brostrøms formulering i Den Store Danske Encyklopædi: "Genkommende motivstørrelser i epik og dramatik er fx dobbeltgængeren, den indbildt syge, trolden der tæmmes, de tre søskende, den evige trekant af elskende, rejsen og hjemkomsten." (Lund 463)

Motivet svæver et sted mellem det abstrakte, idémæssige tema og handlingen i hele dens figurative fylde. Men fordi det i et eller andet omfang er konkret eller figurativt, kan man pege på det og identificere det, selv om det ikke er lig med den manifeste tekst. Det er ikke fortolkningsafhængigt på samme måde som temaet. Enten er det der, eller også er det der ikke. Det har noget primitivt og uafviseligt over sig, også i forhold til litterær stil taget i bred forstand.

Motiver kan have forskellig grad af specificitet. At sige at en tekst handler om hjemkomst er så generelt formuleret, at det kan ligne en tematisk bestemmelse, men "hjemkomst" forudsætter dog logisk en aktør og et forløb (der er nogen, der kommer hjem), hvorfor motivet fremstår mindre abstrakt end f.eks. "magt" eller "kærlighed". At sige at en tekst handler om soldatens hjemkomst er mere motivisk specifikt; her fornemmer man et handlingsforløb og en hovedperson. Hvis vi konkretiserer yderligere til soldatens hjemkomst til en kone, der har fundet en anden, fordi hun troede ham $d ø d$, er vi stadig på et endnu mere specificeret motivisk niveau, der dog vil kunne genfindes i mange tekster. Vi er endnu ikke nede på niveauet for det unikke handlingsforløb. Man kan dermed bestemme motivet således, at det altid befinder sig et sted på et kontinuum mellem abstraktion og konkretion, hvor vi har temaet i den ene ende og handlingen, den manifeste tekst, i den anden ende.

Lars Peter Rømhild (Rømhild 198 ff.) har foreslået en, efter eget udsagn "primitiv" men ikke desto mindre meget klargørende systematik for digtningens stof. Der gives tre slags: tankeforestillinger (begreber og ideer), genstandsforestillinger (naturting og lavede ting) og handlingsforestillinger. Den første kategori ligger tæt på temaet, og Rømhild nævner "visdomslitteraturen" som en tydelig empirisk realisering af den; den anden kategori er i sagens natur meget omfattende i henhold til størrelse og skala, da den går fra det mindste (rosen, brevet) til det største (en social institution 
som hoffet eller et naturelement som havet). Det litterære symbol vil typisk forbinde en tankeforestilling med en genstandsforestilling. Den tredje kategori angår alt det, der har med menneskelige eller menneske-lignende aktører at gøre og er dermed eminent narrativ.

Spontant forstår jeg selv motivet som identisk med Rømhilds tredje kategori, dvs. som bestemte relationer eller konstellationer mellem menneskelige aktører, og det er også ofte den forståelse, man finder i ældre litteraturleksika. Det kan tænkes at afspejle en idealistisk litteraturforståelse, hvor de litterære værker primært beskæftigede sig med "evige problemer" (la condition humaine). Men det er klart, at denne motiv-forståelse vil underbelyse motivet, som vi kender det fra kunsthistorien (f.eks. Madonna med barnet), hvor det i udpræget grad går på genstande, opstillinger, tableauer, dvs. noget statisk og ikke-narrativt. Det samme kan til en vis grad gælde en stor del af lyrikken med præference for det sansede, stemnings- og følelsesmæssige og et "lyrisk jeg", der for en stund er trådt ud af den sociale verden.

I nyere tid har man set en mere materialistisk drejning af motivet, uden at begrebet nødvendigvis har været brugt, f.eks. i regi af den omfattende stedsteori eller et fokus på bestemte historiske institutioner, objekter og artefakter og disses litterære repræsentation. Curtius' topologi og Bakhtins begreb om kronotopen, forstået som en forvaltning af sammenhængen mellem tid og rum i litterære værker, har også spillet en rolle. Jeg er ikke selv videre fortrolig med disse traditioner, som synes at ligge tættere på henholdsvis tanke- og genstandsforestillingerne i Rømhilds systematik, men det er klart, at de er yderst væsentlige med henblik på den historiske specificering af (handlings)motiver og den, i videste forstand, materielle indlejring af konstellationer mellem menneskelige aktører. Selv vil jeg gerne arbejde på et mere generelt litteraturteoretisk niveau af fænomenologisk og etisk karakter. ${ }^{2}$

I dette perspektiv kan vi videre definere motivet som en identificérbar konstellation af elementer fra den menneskelige livsverden; i tilfældet "soldatens hjemkomst" impliceres modsætningspar som ud/hjem, krig/fred, civilist/

2 For en introducerende gennemgang af topologien og de andre nyere teoriretninger inden for feltet, se Dahl 2017. 
soldat og dertil en tidslig og erfaringsmæssig dimension uden hvilken dette motiv ikke lader sig tænke. Ved at indføre begrebet "livsverden" impliceres naturligvis også, at motiver er størrelser, der går på tværs af det litterære og den ikke-litterære virkelighed. Nogle motiver må dog gælde for eksklusivt litterære eller i hvert fald kalde på en symbolsk eller metaforisk læsning, f.eks. motiver fra folkeeventyr og folkeviser og fra mytologiske og på anden vis fantastiske tekster, der overskrider naturlovene og dermed også grænserne for den menneskelige livsverden.

Inden for kognitionsforskningen taler man om sociale scripts som f.eks. "restaurantbesøget". Romaner og film kan spare sig en del konkretisering, fordi vi som læsere og seere selv ved så meget om, hvad der almindeligvis foregår ved et restaurantbesøg. Motivet kan ligne det sociale script, fordi det udgør et typisk forløb fra virkeligheden og/eller litteraturen. "Den evige trekant af elskende" er både et litterært motiv og et typisk forløb fra virkeligheden. Gælder det også "Trolden der tæmmes"? Nogle motiver kan virke oplagt trans-historiske, f.eks. "søskende" som Rømhild har en fin gennemgang af med mange eksempler (Rømhild 206 ff.); andre kan virke oplagt historiske eller kulturbundne, f.eks. alt hvad der har med et strengt æres-kodeks at gøre. Der vil sikkert også være eksempler på, at meget almene motiver kan bruges på en historisk specifik måde, ligesom der kan være mere ideologiske eller værdimæssige diskussioner om hvor historisk versus evigt, et givent motiv er.

Mange motiver er selvsagt historisk og kulturelt variable. "Trolden der tæmmes" forudsætter f.eks. et bestemt syn på køn og kønsroller, hvor manden skal sætte kvinden på plads, og hvor hun også selv hemmeligt længes efter det under den overflade af vildskab, som måske ikke helt udtrykker hendes sande natur. Måske er det ikke et motiv til alle tider på samme måde som "Den evige trekant af elskende". Måske vil de polyamorøst progressive også mene, at det sidstnævnte motiv har en udløbsdato, når ingen mere "ejer hinanden".

For den erfarne læser vil motivet under alle omstændigheder træde tydeligere frem og fungere som et script, hvor man anticiperer, hvad der kommer og dermed også kan lade sig overraske af variationer. Et interessant spørgsmål i den forbindelse er selvfølgelig, om motiver bliver gængse, fordi de rent faktisk er typiske i forhold til den menneskelige livsverden, 
eller om det er, fordi de har vist sig utroligt effektive til kunstneriske formål såsom at drive et plot frem. Kommer motiverne mest fra livet eller mest fra litteraturen, det sidste forstået i en næsten darwinistisk forstand som "survival of the fittest"? Det er sandsynligt, at "det tilfældige møde" og forskellige deus ex machina-mekanismer optræder med statistisk overhyppighed i litteraturen i sammenligning med livet. Sådanne motiver kan da også slides ned til klichéer og rene genrekonventioner. I fiktionsformer som film og tv-serier er det måske tydeligere, hvordan bestemte motiver bliver overhyppige, alene fordi de "gør sig godt" visuelt (opdageren, der brat standser og ser grundende ud = den afgørende og intuitive erkendelse er på vej; kvinden, der hænger lidenskabeligt kyssende på manden, der må prøve at låse sin dør op i blinde = heftigt begær der pludselig har meldt sig). På et mere overordnet plotniveau kan man tænke på chefen, der agerer helt irrationelt obstruerende for at øge presset på opdageren. Principielt er det ikke usandsynligt, at disse motiver også kunne observeres i virkeligheden. Men jeg vil tro, at når de i fiktionen gøres til typiske elementer, er det uden statistisk dækning i virkeligheden. På den måde kan motiver komme til at leve deres eget selvstændiggjorte liv. Den pointe skal blot ikke overdrives til, at litteratur altid mest handler om og henviser til anden litteratur. Samtidig vil en del motiver også være både livsverdens-typiske og ekstremt fiktions-effektive med Rømhilds "søskende" som et godt eksempel. Det kan vi alle relatere til, og det åbner et bredt spektrum af narrative muligheder.

For at teste min forståelse af motiv-begrebet, vil jeg nu prøve at sende det igennem to teoretiske filtre som også er to triadiske begrebssystemer hos to af mine yndlings-litteraturteoretikere, Paul Ricoeur og James Phelan. Hvor Ricoeur var tværvidenskabeligt arbejdende fagfilosof af fænomenologisk-hermeneutisk observans, er James Phelan litteraturforsker i en retorisk-narratologisk tradition med særlig interesse for etik. Jeg skal forudskikke, at ingen af dem anvender motiv-begrebet.

\section{PAUL RICOEUR OG DEN TREFOLDIGE MIMESIS}

Paul Ricoeur ser den litterære mimesis som en dynamisk proces i tre distinkte faser: mimesis 1, mimesis 2, mimesis 3 . Fordelen ved den tilgang er, at den bringer ham ud over det gængse og udsigtsløse alternativ mellem 
en et-verdens-teori (konstruktivismen) og en to-verdens-teori (repræsentation som en eller anden variant af en afspejlingsteori).

Mimesis 1, også kalder præfigurationen, er den menneskelige virkelighed, der ligger før den litterære tekst, og som den litterære tekst i en eller anden forstand forholder sig til. Vi finder her hele semantikken omkring menneskelig handling, et netværk af særlige og interrelaterede begreber som agent, mål, motiv, middel, modstander, omstændighed, hjælp, fjendskab, samarbejde, konflikt, succes, fiasko osv. - kort sagt hele det reservoir af begreber, handlings-forestillinger for at bruge Rømhilds begreb, som definerer den menneskelige handlingsverden som et betydningssystem i sig selv sammenlignet med processer i den fysiske verden. I mimesis 1 møder vi også, hvad Ricoeur kalder, den symbolske mediation af handlinger. Menneskelige handlinger giver ikke altid mening ud fra handlingens semantik, men kræver et kendskab til den konventionelle og kontekstuelle verden, de er indlejret i. Handlinger kan i den forstand kræve analyse, som var de en slags litterære tekster. Med et simpelt eksempel fra Ricoeur selv: når et menneske hæver sin arm, kan det betyde flere forskellige ting, afhængig af sammenhængen: Det kan være en hilsen, en stemmeafgivning, et signal til en taxi, for blot at nævne nogle af mulighederne. På den måde er symbolske ressourcer vævet ind over alt i det menneskelige handlingsfelt og dermed også i den litterære repræsentation af disse forhold.

Endelig rummer mimesis 1 et område, som Ricoeur kalder de temporale træk ved menneskelig erfaring og handling. Menneskelig handling og erfaring kan ikke alene anskues som et statisk system af begreber og mediationer. Ricoeur pointerer her tidsligheden som andet og mere end blot det medium, noget andet nødvendigvis må udfolde sig i, nemlig tiden som et kvalitativt aspekt der tilføjer noget til det, der udfolder sig i den.

Mimesis 2 er betegnelsen for den foreliggende litterære tekst og en fase i den samlede proces. Ricoeur kalder denne fase for konfigurationen. Her bliver elementer fra mimesis 1 æltet sammen i plottet og den narrative komposition. Forskellen er, at elementerne nu optræder i en anden orden, som hidrører fra de poetiske arrangementer og den narrative transposition. De adlyder derfor også, i hvert fald til dels, andre regler og normer, end de gør "ude" i virkeligheden, hvorfor det også er her, de kan komme til at leve et selvstændiggjort liv med litteratur, der primært henviser til anden litteratur. 
Mimesis 3, som Ricoeur også kalder refigurationen, angår receptionen af teksten hos læseren. At læseren er med til at konstituere tekstens betydning, er et ukontroversielt tema i nyere litteraturteori. Hos hermeneutikeren Ricoeur udgør det naturligvis en begrebslig ajourføring af klassiske termer som forudforståelse og tilegnelse. Den triadiske model tydeliggør imidlertid, at mimesis 3 trækker på elementer fra både mimesis 1 og 2, fra forforståelsen af den menneskelige virkelighed og fra den kulturelle opøvethed i litterære og fiktionelle motiver og scripts.

Men hvor skal man i mere konkret forstand lokalisere de litterære motiver i Ricoeurs dynamiske proces?

Mange motiver vil kunne lokaliseres til mimesis 1, den menneskelige livsverden, og de genoptræder, beriges eller varieres i mimesis 2. Enkelte motiver kan også tænkes at være eksklusivt litterære, enten i den banale forstand at de er utænkelige inden for rammerne af den kendte fysiske og menneskelige virkelighed, eller i den mere usikre forstand, at de forekommer så usandsynlige, kulørte eller utroværdige, at de kun kan tænkes i litterært regi. Endelig tilhører motivet selvsagt også mimesis 3, fordi det er i læserens og fortolkerens (for)forståelse og genkendelse, at motivet identificeres og måske forstærkes, bekræftes eller kritiseres kulturelt. Motivet forekommer dermed at være et vigtigt tværgående moment $i$ den mimetiske proces. Det er ikke mindst det, der genkendes, genfindes, fortolkes og varieres.

\section{JAMES PHELAN OG DE TRE DIMENSIONER}

\section{VED ENHVER LITTERÆR TEKST}

Ifølge James Phelan kan enhver litterær tekst anskues på tre niveauer eller ud fra tre perspektiver: det syntetiske, det mimetiske og det tematiske (Phelan, Experiencing Fiction 5-6; Phelan Living to Tell about It 20). Det syntetiske er det, der har at gøre med form, med sproglige og kunstneriske greb. Det mimetiske er det, der efterligner virkeligheden, og som taler til vores følelser og genkendelse. Det tematiske er det, en tekst handler om på et overordnet plan eller i overført betydning.

De tre niveauer kan godt være delvist overlappende. En fiktiv person i en tekst er syntetisk, fordi han er lavet af ord; vi kan ikke tage og føle på ham. Men han er samtidig mimetisk, hvis vi spontant interesserer os for 
hans skæbne, som om han var et virkeligt menneske. Og han kan endelig også være tematisk, hvis hans temperament eller skæbne skal illustrere et overordnet princip.

Forskellige typer tekster vil ofte søge at foregrounde det ene niveau frem for det andet, og vi kan tænke os grænsetilfælde, hvor et af niveauerne er næsten totalt dominerende. I konkretistiske digte, der leger med ordene som lydligt materiale og helst vil vække så få forestillinger som muligt i læseren, dominerer det syntetiske. I en realistisk prosatekst, hvor sproget på ingen måde gør opmærksom på sig selv, og hvor vi heller ikke kommer på den tanke, at dette er fortalt med en særlig hensigt, dominerer det mimetiske. Endelig hersker det tematiske i en tekst, hvor et overordnet budskab, et emne, er skudt meget i forgrunden på bekostning af både sproglig form og fornemmelsen af levet liv.

Alle tre dimensioner vil altid være der i et eller andet omfang, og det interessante er derfor ikke så meget overordnet at lave klassifikationerne men i arbejdet med tekster at påvise, hvordan de tre niveauer spiller sammen, overlapper, skiftes til at være i forgrunden og baggrunden.

Hvorfor kan jeg godt lide denne triade? Måske fordi den på samme måde som Ricoeurs kommer ud over en to-verdens-opstilling, i dette tilfælde mellem det syntetiske på den ene side (tit kaldet det æstetiske eller det specifikt-litterære) og tekstens "indhold" på den anden side, som ofte bliver et lidt uteoretiseret rodsammen af tematiske, motiviske og mimetiske elementer. Phelan komplicerer denne vulgær-dekonstruktive tænkemåde, også i pointeringen af overlap og foregrounding. En tekst vil sjældent kunne det hele lige godt på én gang, og det er ikke nødvendigvis et litterært kvalitetsproblem. Selv om det også godt i visse tilfælde kan fungere som en positiv målestok for kvalitet.

Hvad kan denne triade i forhold til motiv-begrebet? Som hos Ricoeur kan filtreringen tjene til at tydeliggøre motivets tværgående eller "mellemliggende" status i forhold til vores konventionelle opfattelser af tekstlige niveauer: Motivet må for det auktoriale publikum ligge et sted mellem det tematiske og det mimetiske, måske som en tematisk anelse i det mimetiske engagement (når man tænker over en mulig almengørelse af specifikke konflikter i en tekst) eller som et mimetisk overskud i den tematiske refleksion ("denne roman handler om kærlighed, men det er 
sandelig kærlighed i net-datingens tid"). Samtidig vil et givet motiv kunne mistænkes for egentligt at være syntetisk (udelukkende litterært), for det kan indvendes, at sådan er virkeligheden aldrig eller sådan er den kun i en bestemt ideologisk optik (Trolden der tæmmes). Ideologikritik er måske i virkeligheden at kritisere temaer og motiver for at være syntetiske, i betydningen fordrejede og undertrykkende.

\section{VAR DET IDEOLOGIKRITIKKEN, DER FIK MOTIVET TIL AT BLIVE VÆK?}

Hævder man, som det her er gjort, at motiver er forankrede i den menneskelige livsverden, tilkender man dem en form for sandhedsgehalt. I en ideologikritisk og historisk optik vil dette blive mødt med skepsis. I den topologiske tradition taler man om "commonplaces" eller topoi, der i deres lange tradering efterhånden er blevet nedslidte, blevet til klichéer. Måske var det sandt en gang, men tiden er løbet fra det, eller litterært er det blevet så udnyttet, at det har mistet sin friskhed.

Over alt hvor vi i virkeligheden eller litteraturen møder formuleringer af generelle erfaringer, nedarvet visdom, livslove o. lign. $i$ en vis figurativ iklædning, står vi over for motiver. Det gjaldt nok især for den ældre litteratur, jf. denne præcise beskrivelse fra Søren Schou på forskellen mellem ældre og nyere realisme:

Det deterministiske præg i den ældre realisme (...) er tæt forbundet med en typiserende menneskeopfattelse, som sprogligt ofte bliver gjort eksplicit gennem såkaldt apodeiktiske (ubetingede, uomstødelige, ngh) udsagn, dvs. generaliserende fortællerkommentarer, der karakteriserer et fænomen eller et menneske gennem reference til et påstået almengyldigt forhold, som læseren formodes at opfatte på samme måde som forfatteren. Balzacs fortællere var storleverandører af apodeiktiske udsagn (...) Nyrealismen undgår (...) ræsonnementer, der henviser til en fond af almenviden om menneskelivet, sådan som vi finder det hos Balzac og Paludan. Det apodeiktiske udsagn var hjemmehørende i en tid, hvor pagten mellem fortæller og læser - eller i hvert fald illusionen om en sådan pagt endnu gjaldt. Den pagt er opsagt i nyrealismen. (Schou 315)

Det kan være svært her i karakteristikken at se, hvad der er kunstnerisk, og hvad der er historisk-epistemologisk udvikling. Er pagten opsagt, fordi 
der ikke længere findes en sådan almenviden om menneskelivet (i hvert fald ikke uden at den opfattes som problematisk eller mistænkelig), eller er det fordi den i særlig grad skurrer i ørene i netop litterær sammenhæng? Almenviden om menneskelivet bliver i det moderne arbejdsdelt samfund i vidt omfang udparcelleret og professionaliseret som videnskab og ekspertise. Autoritet ekspliciteres og horisontaliseres, selv om den mere intuitive livsvisdom vel også dyrkes i talk shows og erindringsbøger. Man kan forestille sig, at skønlitterære forfattere på samme måde skal smyge en gammel autoritetsrolle af sig, dyrke deres metier, som i modernistisk forståelse primært er af sproglig, æstetisk art og ikke komme og "kloge sig".

Schou taler primært om det fortællemæssige, som vi også kan kalde det gnomiske (den ordsprogsagtige "visdom" som vi ofte finder udtrykt hos den alvidende fortæller), men spørgsmålet er om det ikke er i slægt med det motiviske, som vi vil finde i handlingsgangen snarere end i kommentaren selv om motivet selv sagt også kan tydeliggøres her. Både det gnomiske og det motiviske er for et ideologikritisk blik generaliserede på en suspekt måde. Og måske samtidig klodsede for et æstetisk (modernistisk) blik. Det har dog vist sig noget lettere at uddrive det gnomiske fra fortælleformen end det motiviske fra handlingsgange. Det første kræver blot en anden stil, det andet er formentligt umuligt, fordi handlingsgange altid vil indeholde genkendelige elementer.

Men måske kan vi her øjne en bagvedliggende ideologikritisk årsag til under-teoretiseringen af motivbegrebet i nyere litteraturteori. Motiver har med generalisering at gøre. Generalisering er gammeldags, reaktionær og falsk, og motiver er dermed altid syntetiske og konstruerede, man skal ikke bilde sig andet ind. Eller i en tænkt replik til Ricoeur: Der er ikke et troværdigt almenhedsniveau i litteraturen, et skema man kan tilegne sig til erkendelsesbrug; hermeneutikken må altid munde ud i at være mistænksom, historiserende og konstruktivistisk.

\section{MOTIVER I IDA JESSENS HVIUM-TRILOGI}

Her til sidst vil jeg inddrage et litterært eksempel, Ida Jessens Hvium-trilogi med romanerne: Den der lyver (2001), Det første jeg tænker på (2006) og Børnene (2009). Det er ikke tænkt som et analyse-eksempel, hvad pladsen 
ikke tillader, men mere som en fortsat refleksion nu gennem litteratur fremfor teori. Relevansen af en rehabilitering af motiv-begrebet bør naturligvis også måles i forhold til litterære værker: Får man noget ud af at tilgå værket med en motiv-interesse, som man ikke ville få ved andre typer tilgange? Mit eksempel er tilfældigt valgt. Jeg har for nylig undervist i Ida Jessens romaner, og de bød sig dermed til som materiale, selv om jeg ikke har forfulgt en motivisk interesse i dem tidligere.

De tre romaner i Ida Jessens Hvium-trilogi: Den der lyver (2001), Det første jeg tænker på (2006) og Børnene (2009), er ikke alene bundet sammen ved, at de alle tre foregår i den fiktive lilleby Hvium på kanten af Limfjorden. De har også, når man kigger efter, et fælles motiv, som er kraftfuldt og handlings-genererende: En fremmed kommer til byen. Dette motiv er et af de uopslidelige inden for litteratur, film og fortællinger. Der er nemlig mulighed for en heftig individuel identifikation, når vi som læsere i takt med protagonisten bevæger os gradvist ind i et ukendt univers. Han eller hun er vores inkarnerede repræsentant. ${ }^{3}$ Motiver er som nævnt karakteristiske situationer i den menneskelige livsverden, med en større eller mindre grad af almenhed. I den moderne verden er der flere, der får erfaringer af at være den fremmede. Man kan inspireret af Marianne Horsdals narrative interviews og livsforløbsanalyser måske ligefrem sige, at den moderne livsbiografi er sekventielt stykket sammen af "en fremmed kommer til byen" - fortællinger, hvor det er os selv, der er den fremmede, der igennem vores livsbane skal ankomme til og begå os på forskellige sociale arenaer (Horsdal 21).

Motivet turneres forskelligt i de tre bind, og det er med til at gøre trilogien særdeles afvekslende. I første bind Den der lyver former det en uhyggelig undergangsfortælling. Lægen Christian kommer for at slå sig ned som praktiserende i Hvium og virkelig sætte sit præg på den. Det går af forskellige grunde ikke så godt, byen vender sig voldsomt mod Christian, og til sidst går han til grunde. I andet bind Det første jeg tænker på er fortælleren Birgitte på sin vis kun en biperson på midlertidigt ophold og mest

3 I denne flygtningetid er det parentes bemærket interessant, at der, så vidt jeg ved, ikke findes mange litterære eller filmiske eksempler på motivet "en større gruppe af fremmede kommer til et samfund". 
af alt vidne til romanens centrale handling, hvor en tidligere ankommen, præsten Lisa, skal håndtere, at hendes lille søn er blevet kørt ihjel af en flugtbilist fra sognet. Birgitte prøver også at gøre sig gældende i Hvium på sine egne lidt skæve storby-præmisser, men det har hun ikke så meget held med. Til gengæld bruger hun erfaringen til at holde dommedag over sig selv og få lidt mere styr på sit liv hjemme i storbyen. Tredje bind Børnene er særlig interessant, fordi en fremmed, Solvej, her kommer til byen og bliver der, lader sig integrere. For at kunne skildre denne proces må romanen strækker sig over en årrække (1992-2007) i modsætning til de to foregående, som er fortættede i tid (henholdsvis et år og en sommer), og den bliver på en måde næsten en moderne slægtsroman på de nye sammenbragte familieformers betingelse.

Er Hvium-trilogien udkantslitteratur? Egentlig ikke. Det er ikke min vurdering, at Ida Jessen tilstræber en litterær "behandling" af udkanten, det være sig nostalgisk, dysforisk eller bare nøgternt beskrivende. Det, der interesserer hende ved det lille samfund, er den interpersonelle og sociale kompressionseffekt, hvor mennesker, som er meget forskellige, skal leve tæt på hinanden og være tvunget til at omgås, måske over mange år. Hvium er ikke mindst modbilledet til det senmoderne storbysamfund, hvor mennesker kan leve i lige dele anonymitet og kulturel/klassemæssig segregering. Kompressionen er en velegnet rammesætning for en række af motiver (konflikter), som for en dels vedkommende udløses af hovedmotivet "En fremmed kommer til byen". Den fysisk-geografiske kompression bliver en psykologisk-eksistentiel-etisk-kompression, hvor mennesker virkelig får med hinanden at gøre. Det ligger i øvrigt implicit i motivet "En fremmed kommer til byen", at der er tale om en mindre by, hvor en fremmed overhovedet registreres (og vækker furore) som sådan. "Ankomsten til storbyen/ Paris/København" er en helt andet historie. Her vil dramaet primært ligge hos den enkelte, mens samfundet/byen som en helhed er indifferent og ikke noterer den fremmedes eksistens.

Børnene indtager som nævnt en særstilling i trilogien, fordi den strækker sig over en længere årrække, hvor de to første romaner rummer tidsligt kondenserede handlingsforløb med enkelte flash backs. Det centrale og særlige motiv for denne roman er forholdet mellem skilsmisseforældre og børn. 
Det er ikke ualmindeligt med romaner og film, der handler om utroskab, skilsmisse, kaos og sammenbrud i den senmoderne familie. Og det er heller ikke ualmindeligt med romaner og film om børn, der er blevet store eller voksne, og nu holder opgør med deres forældre på grund af det kaos, de i sin tid blev udsat for. Men med moderne litteraturs forkærlighed for de korte tidslige forløb bliver disse to (eminent sammenhængende) motiver sjældent bragt sammen inden for én og samme fremstilling. Enten er børnene magtesløse genstande for forældrenes hærgen eller også er forældrene magtesløse boksebolde for børnenes harmdirrende anklager. Sket er sket. Sådan er det jo. Konfliktstoffet bliver nok fremstillet og udlevet, men på en måde også afmonteret og i hvert fald ikke bearbejdet gennem denne motivisk og tidsligt énsidige behandling. I Børnene får vi motivet "skilsmisser med børn involveret" udfoldet på et højere og mere sammensat niveau, temporalt og reciprokt: Vi får både moderens og datterens reaktioner på hinanden, i forskellige livsaldre.

Ved romanens begyndelse ankommer Solvej til Hvium; hun er desperat rejst tværs gennem landet for at være tæt på sin datter dér, hvor hendes eks-mand og nye kone har slået sig ned, efter at hun selv underligt uanfægtet før romanens handling forliste sit ægteskab gennem en affære og også gav afkald på datteren. Det lykkes for Solvej med nogen møje at få sig etableret som sundhedsplejerske i Hvium og få et forhold til datteren, med tiden endda i den omfattende forstand, at eks-manden efter en ny skilsmisse rejser fra såvel Hvium som datter. Men nemesis venter. Datteren gør voldsomt oprør mod sin mor og sin barndom, hun forlader Solvej og Hvium, og kun under store prøvelser lykkes det Solvej at få hende tilbage - endnu en gang. Det udfoldede og sammensatte motiv udmærker Børnene som en usædvanlig roman.

Skilsmisser - og deres konsekvenser for børnene - er følsomt stof i vores nutidige samfund, fordi befolkningen de facto er delt, hvad angår praksis: Omkring halvdelen af alle indgåede ægteskaber bliver opløst. Det er derfor svært at hævde en norm uden at fremmedgøre eller udskamme den (anden) halvdel, som vil falde uden for normen. Men det bevirker samtidig, at visse ting ikke kan diskuteres, f.eks. det underlige paradoks blandt yngre eller midaldrende, at børnene på den ene side betyder meget, næsten alt, (jf. romanens titel som godt kan læses med definitive skæb- 
nebasuner) og voldsomt meget mere end for tidligere generationer (de er ønskebørn og livsprojekter), og på den anden side, at mange voksne tilsyneladende lader sig føre underligt viljesløst med af begærets tilfældige nedslag med utroskab og skilsmisser til følge - og med voldsomme konsekvenser for netop de børn, der ellers betyder "alt" og det gør de så alligevel ikke. Det er konfliktstoffet, som der bores i med det integrerede motiv i Børnene. Bl.a. med en effektfuld overførsel af den lidenskabelige og ulykkelige kærligheds faste elementer - længsel, fortvivlelse, desperation, svigt, hævn - på forholdet mellem mor og datter. Der drages selvfølgelig ikke i romanen nogen håndfaste konklusioner om, hvad det er "det rigtige" at gøre. Men den viser nogle sår frem og holder dem åbne. Og det gør den ved at lave en temporal udstrækning og gennemarbejdning af et motiv - skilsmisseforældre og børn - der almindeligvis "klippes af" i den ene eller den anden ende.

\section{KONKLUSION}

Som begreb er motivet på påfaldende vis blevet væk i moderne litteraturteori. Det kan skyldes en naturlig begrebshistorisk udvikling, hvor dets funktion er overtaget af andre, både skarpere og mere nuancerede, teoretiske greb. Det kan også skyldes en bestemt (fag)politisk udvikling i litteraturfaget fra en form for idealisme med konservative overtoner til en form for materialisme med progressive overtoner. Måske er motivet blevet kontroversielt af politiske og kulturkritiske grunde, fordi det mistænkes for at være født konservativt, født gnomisk.

Risikoen ved motivets bortfald er på det strikte faglige plan, at det bliver svært at bedrive litteraturvidenskab på indholdssiden som andet end en lidt begrebsdiffus og æstetisk omvejspræget underafdeling af Cultural Studies eller historie-faget. Men måske er det motiviske niveau dér, hvor man skal søge litteraturens positive erkendelsesmæssige potentiale. Vanskelighederne i nærværende artikel med at indplacere motiv-begrebet i holistiske begrebssystemer for litteraturen som Paul Ricoeurs og James Phelans teoretiske triader viser indirekte, at motivet har med den litterære erkendelse som sådan at gøre; det er ikke et moment, der let lader sig isolere på en bestemt plads i en begrebsarkitektur. 
Det har ikke været muligt inden for rammerne af nærværende artikel at gå dybt ind i en diskussion af de analytiske og fortolkningsmæssige konsekvenser ved en rehabilitering af motiv-begrebet. Men det lille eksempel med Ida Jessens Hvium-trilogi kan forhåbentlig vise, at den motiviske indgang kan åbne for iagttagelser, man måske ikke ville være nået til med mere traditionelle tematiske og tekstanalytiske tilgange.

Nils Gunder Hansen er professor i tekst- og kulturanalyse ved Institut for Kulturvidenskaber, Syddansk Universitet. Kritiker og klummeskriver ved Kristeligt Dagblad. Seneste antologi (redigeret sammen med Ivy York Möller-Christensen) Etik til forhandling. Litteratur - Film - TV, Dansklærerforeningens Forlag 2015.

\section{THE MOTIF THAT VANISHED FROM LITERARY THEORY}

The article argues that classical concepts in literary theory such as "motif" and "theme" have been undertheorized in recent decades. They have been taken for granted as "ordinary language"-vocabulary in no need of conceptual clarification. But the dimension of content in a literary text cannot be sufficiently theorized without precise definitions of "motif" and "theme". The article claims that the theme is always an abstract concept, an idea, extrapolated from the text by its interpreter, whereas the motif presents itself in the text as an observable constellation between mimetic elements from the human life world that can be traced with variations through multiple texts or other fictional modes. The motif can be more or less specified and will always be located somewhere on a continuum between the abstract theme and the individual text. The article then tries to enrich this understanding of the motif by confronting it with the textual theories of Paul Ricoeur and James Phelan. It is furthermore discussed whether the critique of ideology in the Marxist years played a role in the marginalization of the motif. The relevance of the reconstructed concept is finally demonstrated in an outline of an analytical approach to three novels (The "Hvium"-trilogy) by the Danish author Ida Jessen and it is concluded that this type of approach enables observations that would have been less obvious entering the textual universes on higher or lower levels than the motif being always in between the theme and the text. 


\section{KEYWORDS}

EN: literary theory, motif, theme, life world, critique of ideology, Ricoeur, Phelan, Ida Jessen

DA: litteraturteori, motiv, tema, mimesis, livsverden, ideologikritik, Ricoeur, Phelan, Ida Jessen

\section{LITTERATUR}

Dahl, Christian. "Topos og motiv: et forskiningshistorisk rids", K\&K 123, 2017, s. 23-36.

Horsdal, Marianne. " Livsløbets sprogspil. Fortælling som erkendelsesform og konstruktion". Livet som indsats. Livshistoriske satsninger og iscenesættelser. Red. Svend Halse. Odense: Syddansk Universitetsforlag, 2004. 11-26.

Kayser, Wolfgang. Das sprachliche Kunstwerk. Eine Einführung in die Literaturwissenschaft, Bern: A Francke AG Verlag, 1948.

Kjældgaard, Lasse Horne m.fl. (red). Litteratur. Introduktion til teori og analyse, Gylling: Aarhus Universitetsforlag, 2013.

Illum Hansen, Thomas. "Fæno... hvad for noget? Om forholdet mellem litteratur og fænomenologi", KRITIK 172 (2004): 5-14.

Lund, Jørn (red). Den Store Danske Encykloplædi, bind 13, Haslev: Gyldendal, 1999.

Nielsen, Erik. "Om tema". Om litteraturanalyse. Red. Lis Møller. Odense: Systime, 1995. 45-76.

Phelan, James. Living to Tell about It. A Rhetoric and Ethics of Character Narration, New York: Cornell University Press, 2005

Phelan, James. Experiencing Fiction: Judgments, Progressions, and the Rhetorical Theory of Narrative, Columbus: The Ohio State University Press, 2007.

Ricoeur, Paul. Temps et récit. Tome 1, Paris: Seuil, 1983.

Rømhild, Lars Peter. Slags. Om litterære arter, genrer, motiver, Viborg: Gyldendal, 1986.

Schou, Søren. "Det nye ved nyrealismen". Historier om nyere nordisk litteratur og kunst. Red. Anne-Marie Mai og Anne Borup. København: Gads Forlag, 1999.

Tygstrup, Frederik. På sporet af virkeligheden, København: Gyldendal, 2000. 